\title{
Indoxyl sulfate promotes apoptosis in cultured osteoblast cells
}

\author{
Young-Hee Kim ${ }^{1}$, Kyung-Ah Kwak', Hyo-Wook Gil ${ }^{*}$, Ho-Yeon Song ${ }^{1}$ and Sae-Yong Hong ${ }^{2}$
}

\begin{abstract}
Background: Indoxyl sulfate (IS), an organic anion uremic toxin, promotes the progression of renal dysfunction. Some studies have suggested that IS inhibits osteoclast differentiation and suppresses parathyroid hormone (PTH)-stimulated intracellular CAMP production, decreases PTH receptor expression, and induces oxidative stress in primary mouse calvaria osteoblast cell culture. However, the direct effects of IS on osteoblast apoptosis have not been fully evaluated. Hence, we investigated whether IS acts as a bone toxin by studying whether IS induces apoptosis and inhibits differentiation in the cultured osteoblast cell line MC3T3-E1.

Methods: We assessed the direct effect of IS on osteoblast differentiation and apoptosis in the MC3T3-E1 cell line. We examined caspase-3/7 activity, apoptosis-related proteins, free radical production, alkaline phosphatase activity, and mRNA expression of type 1 collagen and osteonectin. Furthermore, we investigated the uptake of IS via organic anion transport (OAT).

Results: We found that IS increased caspase activity and induced apoptosis. Production of free radicals increased depending on the concentration of IS. Furthermore, IS inhibited the expression of mRNA type 1 collagen and osteonectin and alkaline phosphatase activity. The expression of OAT, which is known to mediate the cellular uptake of IS, was detected in in the MC3T3-E1 cell line. The inhibition of OAT improved cell viability and suppressed the production of reactive oxygen species. These results suggest that IS is transported in MC3T3-E1 cells via OAT, which causes oxidative stress to inhibit osteoblast differentiation.
\end{abstract}

Conclusions: IS acts as a bone toxin by inhibiting osteoblast differentiation and inducing apoptosis.

Keywords: Uremia, Renal osteodystrophy, Apoptosis, Cell differentiation, Organic anion transporters

\section{Background}

Indoxyl sulfate (IS) is an organic anion uremic toxin belonging to the family of protein-bound retention solutes [1]. IS is synthesized in the liver from indole, which is produced from the metabolism of dietary tryptophan in the body. The studies performed to date have shown that IS accumulates in blood and promotes the progression of renal dysfunction [2-5]. IS may also act as a vascular toxin $[2-4,6]$. It directly stimulates rat vascular smooth muscle cell proliferation in a concentrationdependent manner. Furthermore, Dahl salt-sensitive hypertensive rats administered IS in combination with a high-salt diet have been found to show an increase in

\footnotetext{
* Correspondence: hwgil@schmc.ac.kr

${ }^{2}$ Department of Internal Medicine, Soonchunhyang University Cheonan Hospital, 31 Soonchunhyang 6gil, Dongnam-gu, Cheonan, Chungnam 330-721, Korea

Full list of author information is available at the end of the article
}

aortic wall thickness and severe aortic calcification, with colocalization of osteoblast-specific proteins such as Cbfa-1, osteonectin, and alkaline phosphatase [7]. In a recent study, Iwasaki et al. reported that when rats with renal dysfunction and low bone turnover were administered an oral adsorbent, their blood IS level decreased and osteoblastic cell function improved [8]. Iwasaki et al. have also shown that in primary mouse calvaria osteoblast cell culture, addition of IS suppresses parathyroid hormone (PTH)-stimulated intracellular cAMP production, decreases $\mathrm{PTH}$ receptor expression, and induces oxidative stress [9]. IS inhibits osteoclast differentiation and bone-resorbing activity, which could affect bone remodeling in chronic kidney disease patients [10]. Limited data suggest that IS could act as a bone toxin by affecting both osteoblast and osteoclast activities. To

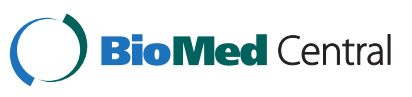

(C) 2013 Kim et al.; licensee BioMed Central Ltd. This is an open access article distributed under the terms of the Creative Commons Attribution License (http://creativecommons.org/licenses/by/2.0), which permits unrestricted use, distribution, and reproduction in any medium, provided the original work is properly cited. 
date, the direct effects of IS on osteoblast apoptosis have not been fully evaluated.

Hence, we investigated whether IS acts as a bone toxin by studying whether IS induces apoptosis and inhibits differentiation in a cultured osteoblast cell line.

\section{Methods \\ Chemicals}

L-Ascorbic acid, $\beta$-glycerophosphate, probenecid, probucol, $\mathrm{N}$-acetylcysteine (NAC), and IS were all obtained from Sigma (St. Louis, MO, USA). All cell culture media and supplements were from Hyclone (Logan, UT, USA). Reagents for reverse transcription and those for realtime PCR reactions were from Toyobo (Osaka, Japan). Anti-Bax, Anti-Bcl-2, and anti-p53 mouse monoclonal antibodies were purchased from Santa Cruz (Santa Cruz, CA, USA). Secondary goat anti-rabbit IgG was obtained from Thermo Fisher Scientific (Rockford, USA). The assay kit for caspase-3/7 activity was purchased from Promega (Mannheim, Germany).

\section{Cells and osteogenic induction}

Newborn mouse calvaria-derived MC3T3-E1 subclone 14 pre-osteoblastic cells (ATCC, USA) were cultured in $\alpha$-MEM medium (Hyclone) supplemented with $10 \%$ fetal bovine serum (Hyclone), $100 \mathrm{U} / \mathrm{mL}$ penicillin, and $100 \mathrm{mg} / \mathrm{mL}$ streptomycin (Hyclone) at $37^{\circ} \mathrm{C}$ in an atmosphere with $100 \%$ humidity and $5 \% \mathrm{CO}_{2}$. Osteoblast differentiation was induced by the addition of $10 \mathrm{mM} \beta$ glycerophosphate, as described previously [11].

\section{Cell viability}

Cell viability was assessed using the 3-(4,5-dimethylthiazol-2-yl)-2,5-diphenyltetrazolium bromide (MTT) assay, as described previously [12]. MC3T3-E1 cells were incubated in osteogenic induction medium with or without IS at $37^{\circ} \mathrm{C}$ for $72 \mathrm{~h}$. After the cells were lysed with DMSO solution, the optical density was measured at $590 \mathrm{~nm}$ using the optical density at $630 \mathrm{~nm}$ as reference (VICTOR $^{\mathrm{Tw}} \mathrm{X} 3$; PerkinElmer, USA).

\section{Bone differentiation}

Alkaline phosphatase (ALP) activity was measured in cells treated with 0-1.5 mM IS and in control cells incubated for 3, 5, 7, and $10 \mathrm{~d}$. Cells were washed with PBS and were lysed with a solution containing $0.1 \%$ Triton $\mathrm{X}-100$ at the same time as the cellular alkaline phosphatase activity and cell protein content were determined. The enzymatic reaction was started by the addition of $50 \mu \mathrm{L}$ of substrate/buffer mixture (equal volumes of $p$ nitrophenol phosphate substrate [N 1891; Sigma Chemicals, St. Louis, MO] and alkaline buffer solution [A9226; Sigma Chemicals]). After 30 min of incubation at $37^{\circ} \mathrm{C}$, the reaction was stopped by adding an equal volume of
$0.05 \mathrm{M} \mathrm{NaOH}$. The lysate from the wells was collected into individual Eppendorf tubes and vortexed. The ALP activity was determined colorimetrically at $405 \mathrm{~nm}$ using $p$-nitrophenol (PNP) standards (0-50 nmol, N7660; Sigma Chemicals). The protein concentration in the lysate was determined using the Bradford assay. ALP activity is expressed as nanomoles of PNP released per milligram of protein.

\section{Assessment of cellular oxidative stress}

Production of intracellular reactive oxygen species was detected using the nonfluorescent cell-permeating compound, 2'-7'-dichlorofluorescein diacetate (DCF-DA). DCF-DA is hydrolyzed by intracellular esterases, and is then oxidized by reactive oxygen species (ROS) to a fluorescent compound, 2'-7'-dichlorofluorescein (DCF). After treatment with $0-1.5 \mathrm{mM}$ IS, MC3T3-E1 cells were treated with DCF-DA $(10 \mu \mathrm{M})$ for $30 \mathrm{~min}$ at $37^{\circ} \mathrm{C}$. Following DCF-DA exposure, the cells were rinsed and then scraped into PBS with $0.2 \%$ Triton X-100. Fluorescence was measured with a plate reader $\left(\mathrm{VICTOR}^{\mathrm{m}} \mathrm{X} 3\right.$ ) with excitation at $485 \mathrm{~nm}$ and emission at $535 \mathrm{~nm}$.

\section{Flow cytometry analysis of apoptosis}

Quantification of cells undergoing programmed cell death was conducted using an annexin V-propidium iodide apoptosis kit (Invitrogen). Analyzed cells were washed once in phosphate-buffered saline and resuspended in the binding buffer provided. Annexin V (Alexa 488-conjugated) and propidium iodide were added and incubated for $15 \mathrm{~min}$ at room temperature in the dark. The cells were analyzed using a FACS Calibur flow cytometer and CellQuest software.

\section{Apoptosis measurement: caspase-3/7 activity, and immunoblot assay for apoptosis-related factors p53, Bcl-2, and Bax}

Caspase-3/7 activity was detected using a Caspase-Glo $3 / 7$ Assay system (Promega) after preincubating the MC3T3-E1 cells $\left(2 \times 10^{5} / 96\right.$-well plate), followed by treatment with various IS concentrations (control, $0.5 \mathrm{mM}, 1 \mathrm{mM}$ ) for $3,6,9,12$, and $24 \mathrm{~h}$. The background luminescence associated with the cell culture and assay reagent (blank reaction) was subtracted from the experimental values. The activity of caspase-3/7 is presented as the mean value of triplets for the given cells. The intensity of the emitted fluorescence was determined at a wavelength of $521 \mathrm{~nm}$ with the use of luminometry (VICTOR ${ }^{\mathrm{TM}} \mathrm{X} 3$ ).

The immunoblot assay was conducted as follows. After stimulation, cells were washed once with phosphatebuffered saline and lysed with radioimmunoprecipitation assay (RIPA) lysis buffer (ROCKLAND, USA) and placed on ice for $30 \mathrm{~min}$. Total cell extracts were centrifuged at 
$14000 \mathrm{~g}$ (for $20 \mathrm{~min}$ at $4^{\circ} \mathrm{C}$ ), and protein-containing supernatants were collected. Equal amounts of proteins $(40 \mu \mathrm{g})$ were resolved by sodium dodecyl sulfate-polyacrylamide gel electrophoresis, transferred to a nitrocellulose membrane, and immunoblotted with specific antibodies against Bax, Bcl-2, and p53. Secondary antibodies were obtained from Thermo Fisher Scientific. Equal loading was confirmed using a $\beta$-actin antibody. Protein expression levels were quantified using a densitometer (ChemiDoc ${ }^{\mathrm{mm}}$ XPS + with Image Lab $^{\mathrm{m}}$ Software, Bio-Rad). The data are represented as the ratio of expression of the target protein to that of $\beta$-actin.

\section{RNA isolation, CDNA synthesis, and PCR analysis}

Total RNA was isolated using an RNeasy Mini Kit (QIAGEN, Tokyo, Japan) according to the manufacturer's instructions. Total RNA $(1 \mu \mathrm{g})$ was used as the template for cDNA synthesis in a $50-\mu \mathrm{L}$ reaction mixture using a reverse transcriptase-PCR kit (TOYOBO) according to the manufacturer's instructions. Real-time PCR was performed on a CFX96 $^{\text {ma }}$ (BIO-RAD). The PCR reactions consisted of Power SYBR Green PCR Master Mix (Applied Biosystems, UK), $0.1 \mathrm{mM}(10 \mathrm{pM})$ specific primers, and $50 \mathrm{ng}$ of cDNA. The primer sequences, designed with Beacon Designer 7.6 software (Bio-Rad), were as follows: mouse osteonectin, $5^{\prime}$ TCTCAACAAACAAATCAGGGAT-3' and 5' '-TGGCAGCACATTCATCTATG-3'; collagen 1, 5' -ATCACCAAACT CAGAAGATGTAG-3' and 5' -CAGGAAGTCCAGGCTG TC-3'; organic anion transport 1 (OAT1), 5-ATG CCT ATC CAC ACC CGT GC-3 and 5-GGC AAA GCT AGT GGC AAA CC-3); OAT3, 5-CAG TCT TCA TGG CAG GTA TAC TGG-3 and 5-CTG TAG CCA GCG CCA CTG AG-3; and GAPDH, 5'-CAAGAAGGTGGTGAAGCA-3' and $5^{\prime}$-TGTTGAAGTCGCAGGAGA-3'.

\section{Statistical analysis}

All results are expressed as the mean \pm standard error of the mean (SEM) values. The mean values of the groups were compared by analysis of variance, and a $P$-value $<0.05$ was considered significant.

\section{Results}

Effect of indoxyl sulfate on cell viability in the MC3T3-E1 cell line

To determine cytotoxicity, the effect of IS on the cell proliferation of MC3E3-T1 was studied using an MTT assay. As shown in Figure 1, IS, at the concentration range of $0.1-1.5 \mathrm{mM}$, inhibited cell proliferation at $72 \mathrm{~h}$.

\section{Gene expression of OATs in the MC3T3-E1 cell line}

Because other studies have shown that IS is transported into osteoblasts and renal tubule cells via OAT, gene expression of OAT-1 and OAT-3 was investigated by real time PCR using RNA extracts. The expression of OAT-3 was relatively higher than that of OAT-1 in the MC3T3-E1 cell line (Figure 2A). After confirming the expression of the OAT gene in the MC3T3-E1 cell line, we investigated whether blocking OAT could prevent IS toxicity. To confirm the role of OAT in MC3T3-E1 cells, probenecid, a transporter inhibitor, was added to the cells during pretreatment with $1 \mathrm{mmol} / \mathrm{L}$ of IS. Blocking OAT in MC3T3-E1 cells improved cell survival (Figure 2B). ROS production was inhibited by probenecid. The effect obtained was similar to that obtained on pretreatment with the antioxidants NAC $(500 \mu \mathrm{M})$ and probucol $(62.5 \mu \mathrm{M})$ (Figure $2 \mathrm{C}$ ). Probenecid works by interfering with the OAT in the kidneys, which blocks the efflux of IS in cells. Probucol is a phenolic lipid-lowering agent with antioxidant and antiinflammatory properties. $\mathrm{N}$-acetylcysteine (NAC) is the

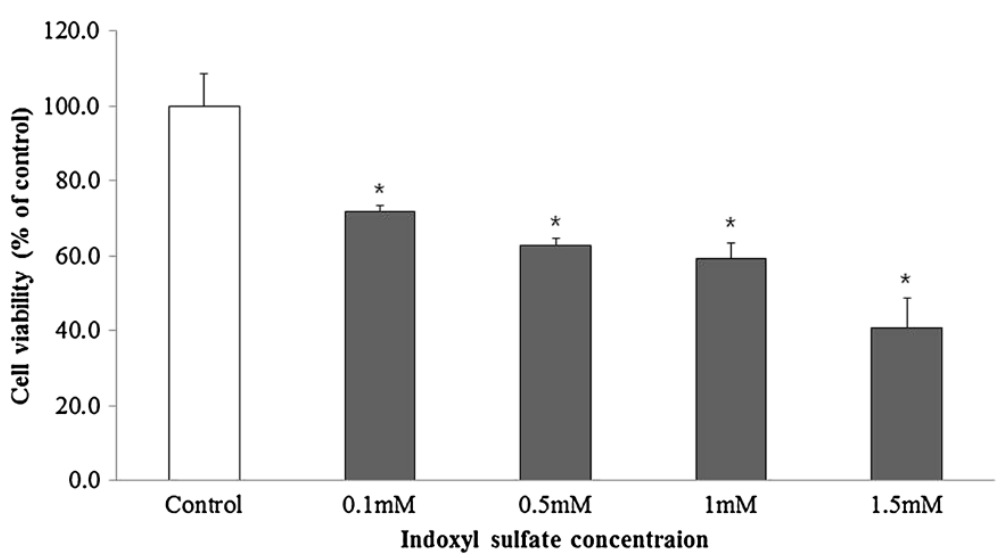

Figure 1 Effect of IS on the viability of MC3T3-E1 cells. Cell number was measured $24 \mathrm{~h}$ after the addition of IS at concentrations ranging from 0.1 to $1.5 \mathrm{mM}$ and was expressed as the percentage of control cells not pretreated with IS (open bar). The cell toxicity of IS was found to be dose dependent. The data represent the mean \pm SEM from 8 replicates in each group. ${ }^{*} P<0.05$ vs. control cells. 


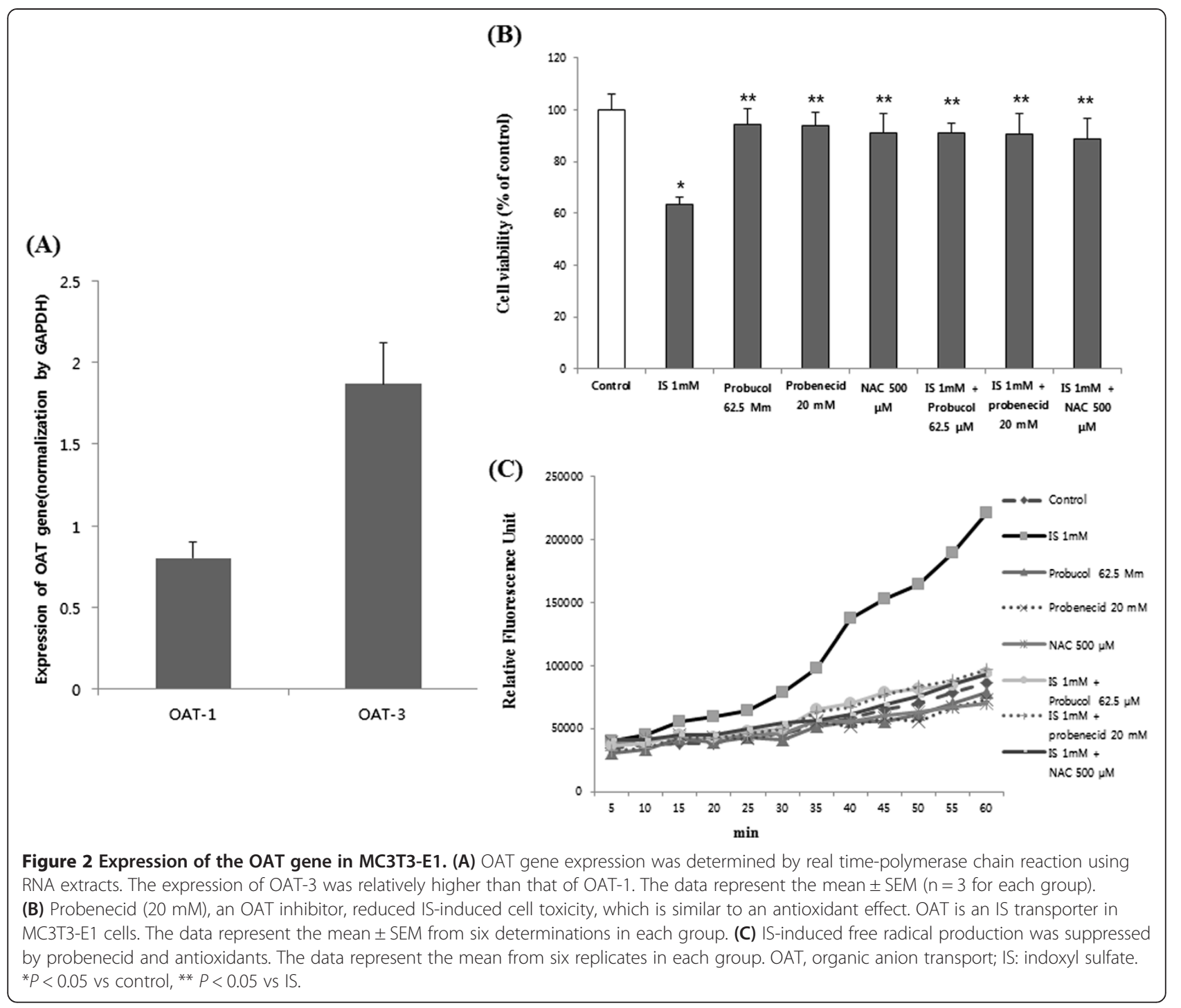

precursor of L-cysteine and therefore of reduced glutathione and has been widely used as an antioxidant.

\section{Intracellular oxidative stress}

As shown in Figure 3, IS increased cellular oxidative stress in a concentration-dependent manner. Addition of antioxidants or the OAT inhibitor suppressed free radical production (Figure $2 \mathrm{C}$, Figure 3 ).

\section{Inhibition of osteoblast differentiation by IS}

To determine the differentiation of the pre-osteoblast cell line, ALP activity was measured in osteogenic induction medium with or without IS. As shown in Figure 4, ALP activity was suppressed above $1 \mathrm{mM}$ IS. Collagen 1 and osteonectin were produced only in differentiated osteoblasts. To determine whether the osteoblasts had differentiated, the expression of collagen 1 and osteonectin mRNA was analyzed using real-time PCR. At $5 \mathrm{~d}$, the production of collagen 1 and osteonectin mRNA was significantly inhibited by the addition of IS, as shown in Figure 5.

\section{Apoptosis induction by IS}

To determine whether IS induces apoptosis, the cells were incubated with different concentrations of IS for $12 \mathrm{~h}$, stained, and subjected to Fluorescence-activated cell sorting (FACS) analysis to measure apoptosis and necrosis. IS increased the proportion of apoptotic cells, particularly in osteoblasts (Figure 6). To elucidate the role of caspases in osteoblasts, we first examined the activity of the executioner caspase-3/7 in response to IS in osteoblasts. The activity of caspases was determined using fluorometric peptide substrates specific to caspase. As shown in Figure 7, the activity of caspase-3/7 peaked 

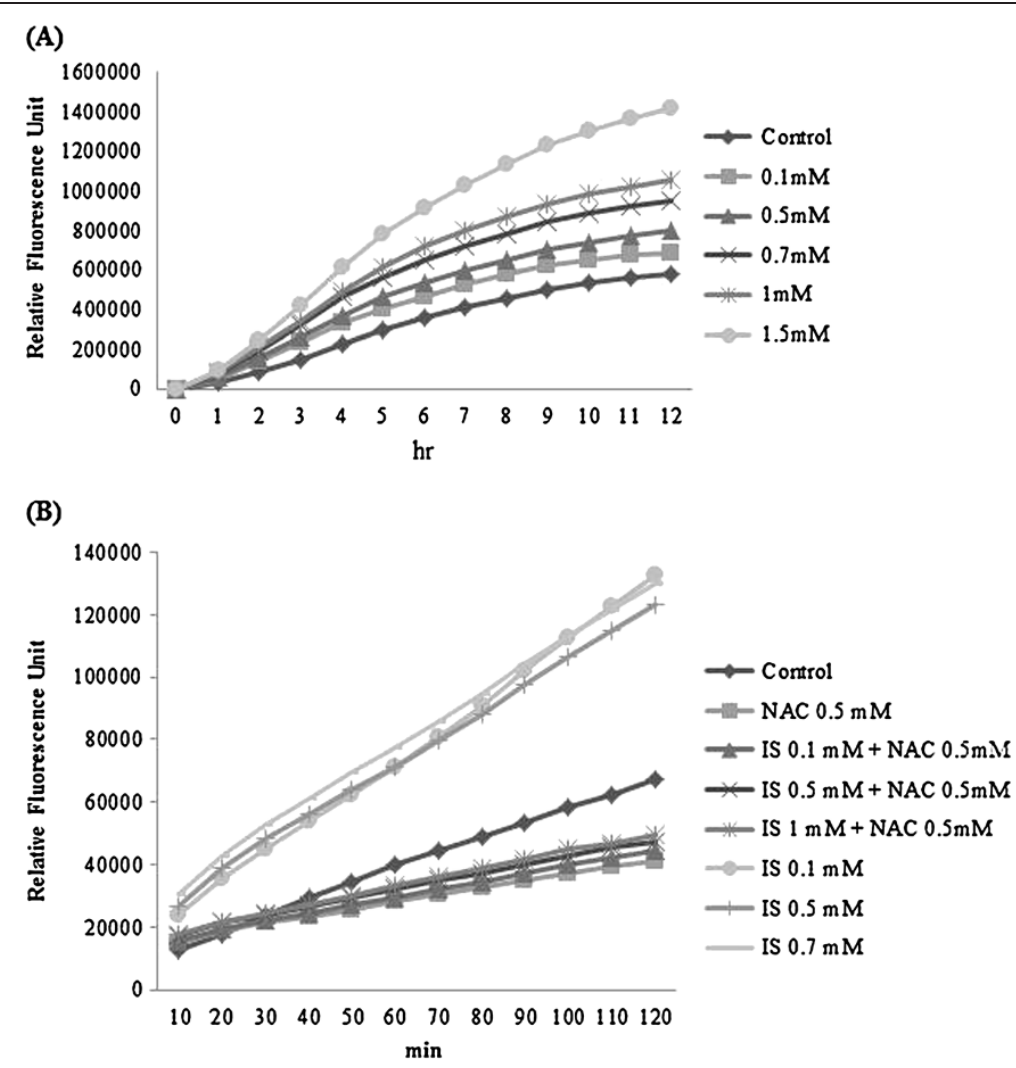

Figure 3 Free radical production induced by the addition of IS. MC3T3-E1 cells were seeded in 96-well plates, IS was added, and free radical production was measured after the indicated time. (A) Free radical production increased with time in a dose-dependent manner. (B) IS-induced free radical production was suppressed by $0.5 \mathrm{mM} \mathrm{N}$-acetylcysteine (NAC). The data represent the mean from six replicates ns in each group.

at $6 \mathrm{~h}$ of incubation with IS $(1.0 \mathrm{mM})$. Caspasedependent apoptosis thus appears to be involved in ISinduced osteoblast toxicity. To determine which apoptosis-related factors may be acting upstream of caspase activation, the expression of $\mathrm{p} 53, \mathrm{Bcl} 2$, and Bax was measured after the addition of IS $(1.0 \mathrm{mM})$. IS increased the expression of Bax and p53, which play a role in apoptosis. However, Bcl-2 was not influenced by IS $(1.0 \mathrm{mM})$ at 1,3 , and $6 \mathrm{~h}$ (Figure 8$)$.

\section{Discussion}

In the present study, we studied whether the uremic toxin IS directly suppressed osteoblast differentiation and induced osteoblast apoptosis via caspase activity.

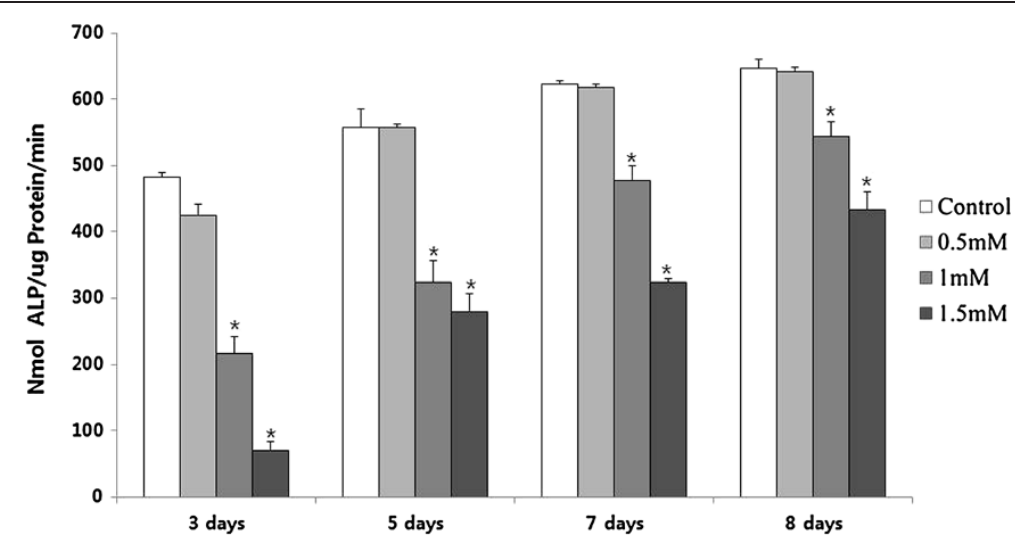

Figure 4 Effect of IS addition on ALP activity in MC3T3-E1 cells. ALP activity was suppressed by IS at concentrations greater than $1 \mathrm{mM}$. ALP activity is expressed as nanomoles of $p$-nitrophenol released per milligram of protein. ALP, alkaline phosphatase $* P<0.05$ vs. control cells at each time point. The data represent the mean \pm SEM ( $n=6$ for each group). 


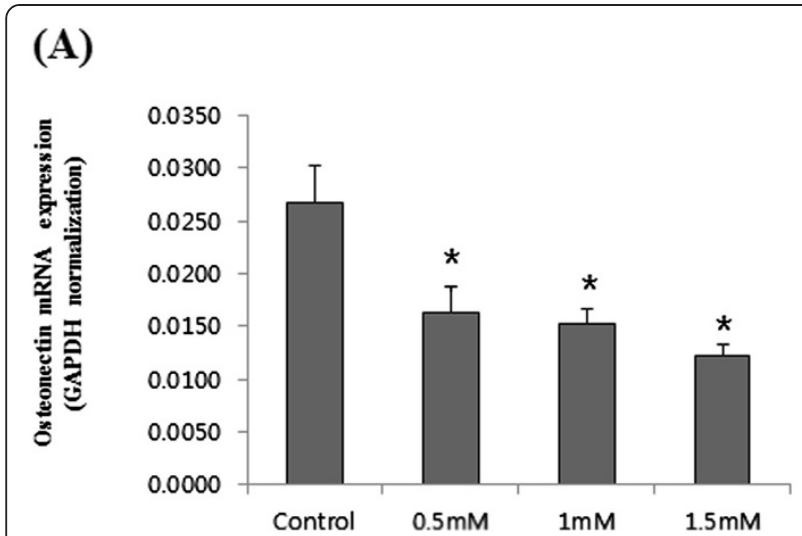

(B)

Figure 5 Changes in collagen 1 and osteonectin gene expression in MC3T3-E1 cells after IS addition. (A) Expression of the osteonectin gene upon treatment with various concentrations of IS at $5 \mathrm{~d}$. (B) Expression of the collagen 1 gene upon treatment with various concentrations of IS at $5 \mathrm{~d}$. ${ }^{*} P<0.05$ vs. control cells. The data represent the mean \pm SEM ( $n=4$ for each group).

Bone toxicity is mediated by IS-induced free radical production, which evokes apoptosis. Our data emphasize the fact that several uremic toxins could affect osteoblast differentiation and function. Recently, several reports have shown that IS may be a bone toxin [8-10]. Iwasaki et al. [8] showed that oral administration of the indoleabsorbing Kremezin prevents the progression of renal failure and improves bone formation in a rat model of chronic kidney disease (CKD) with low bone turnover.
This group also demonstrated that the IS taken up by osteoblasts via the OAT-3 present in these cells augments oxidative stress to impair osteoblast function and downregulate PTH receptor expression [9]. These findings suggested that IS may be a bone toxin that is taken up via OAT-3 in osteoblasts and inhibits bone turnover by free radicals produced because of IS. Our data support the previous studies and suggest that IS itself could induce apoptosis via the production of free radicals.

\section{(A)}

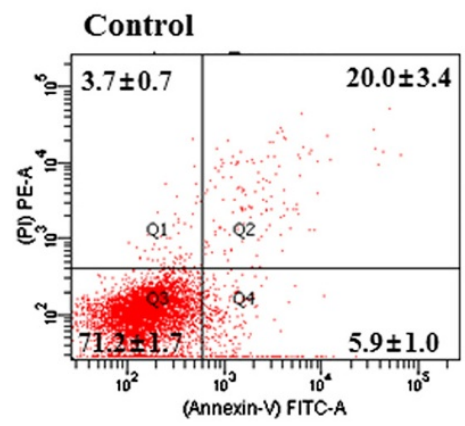

IS $0.5 \mathrm{mM}$

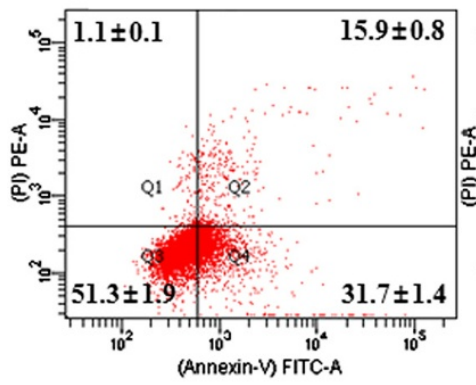

IS $0.1 \mathrm{mM}$

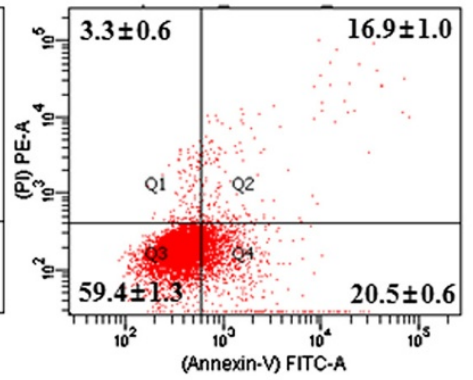

IS $1 \mathrm{mM}$

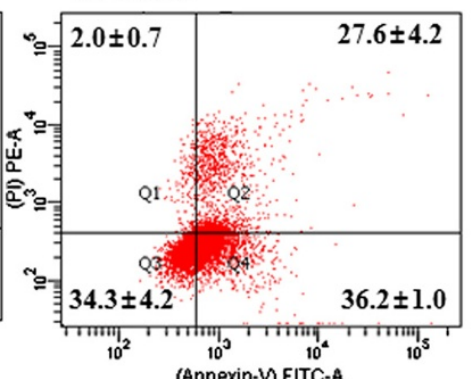

(B)

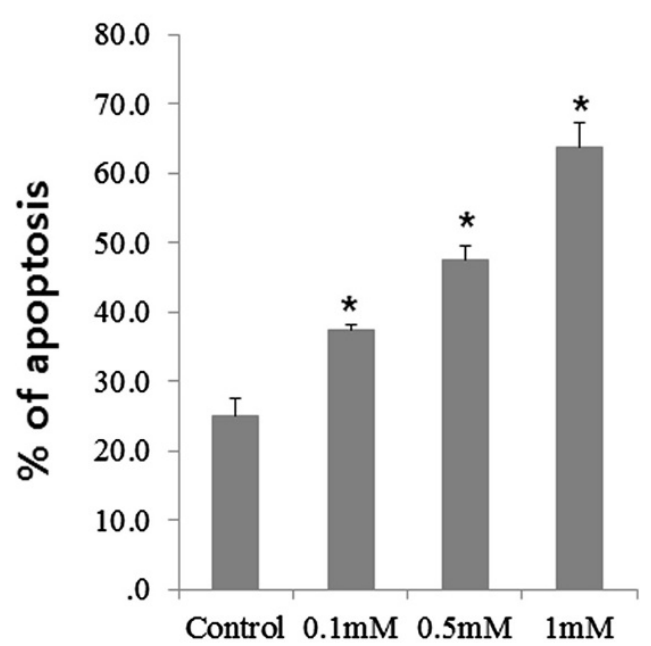

Figure 6 Effect of IS on MC3-T3 cell apoptosis, determined by FACS analysis. (A) Cells were incubated with various concentrations of IS for $24 \mathrm{~h}$, after which they were harvested, the DNA was stained with propidium iodide, and the cells were analyzed using FACS. (B) IS increased the proportion of apoptotic cells in MC3-T3 cells. ${ }^{*} P<0.05$ vs. control cells. The data represent the mean \pm SEM $(n=3$ for each group). 


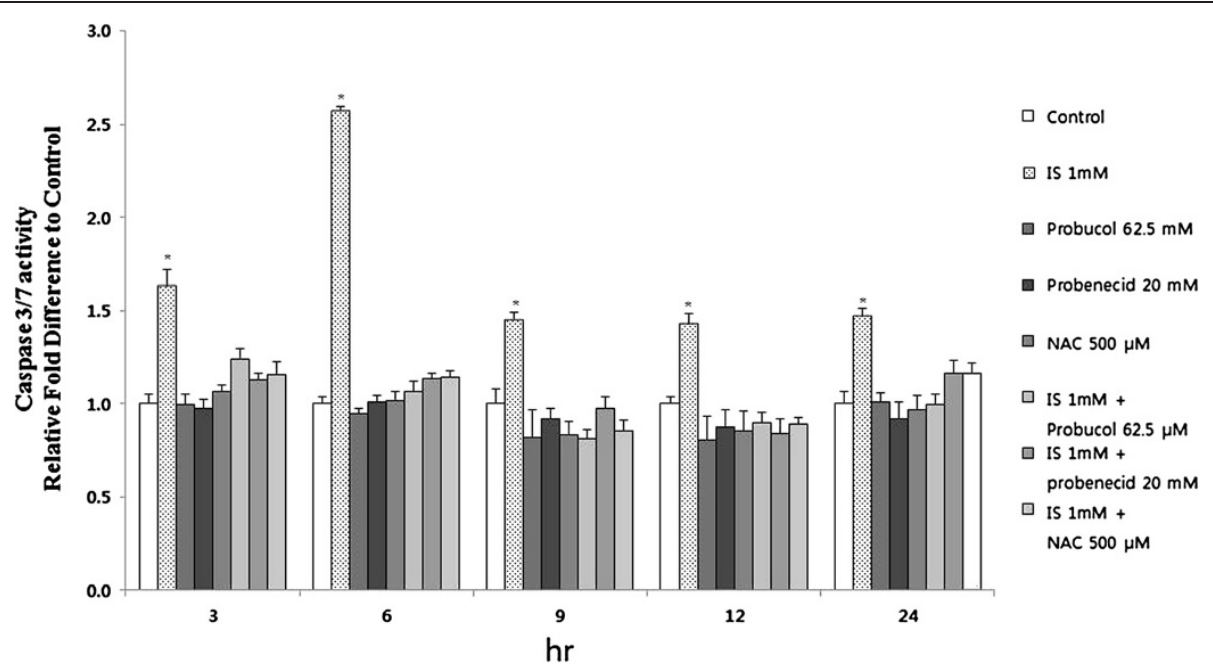

Figure 7 Effect of IS on caspase-3/7 activity. Caspase-3/7 activity was analyzed using a Promega Caspase Glo 3/7 kit (described in the Materials and Methods) Caspase-3/7 activity peaked at $6 \mathrm{~h}$ at $1 \mathrm{mM} \mathrm{IS}$. IS increased caspase- 3/7 activity, but probenecid (20 mM), an OAT inhibitor, attenuated IS- induced caspase-3/7 activity, which is similar to an antioxidant effect. The data represent the mean \pm SEM ( $n=6$ for each group).

${ }^{*} P<0.05$ vs. control cells at each time point.

Our data showed that IS-induced apoptosis is mediated by caspases. It is well established that $\mathrm{p} 53$ positively regulates Bax, but negatively regulates Bcl-2 expression [13]. IS-elicited changes in the Bax protein level are likely to be the result of an increase in p53 [14]. The Bcl-2 family plays a prominent antiapoptotic role by acting upstream of caspase activation. Our data showed that the expression of $\mathrm{Bcl}-2$ is not influenced at 1,3 , or $6 \mathrm{~h}$. The proapoptotic factors Bax and p53 may play a predominant role in IS-induced osteoblast apoptosis, which is activated via the caspase pathway.

Mozar et al. showed that IS inhibits osteoclast differentiation and bone-resorbing activity [10]. Goto et al. [15] reported that IS levels correlated negatively with 2 serum markers of bone formation (alkaline phosphatase and bone-specific alkaline phosphatase) independently of intact PTH, but not with a serum marker of bone resorption (TRAP $5 \mathrm{~b}$ ). Although serum markers may not be ideal for testing bone turnover, on the basis of their results, they suggested that IS may promote low-turnover bone disease outcomes (such as adynamic bone disease) observed in CKD patients.

With CKD progression, the ability of the kidneys to maintain systemic mineral homeostasis gradually decreases, resulting in the various abnormalities of bone and vascular physiology observed in CKD-MBD (CKD associated with mineral and bone disorders) [16]. In high-turnover bone disease, e.g., secondary
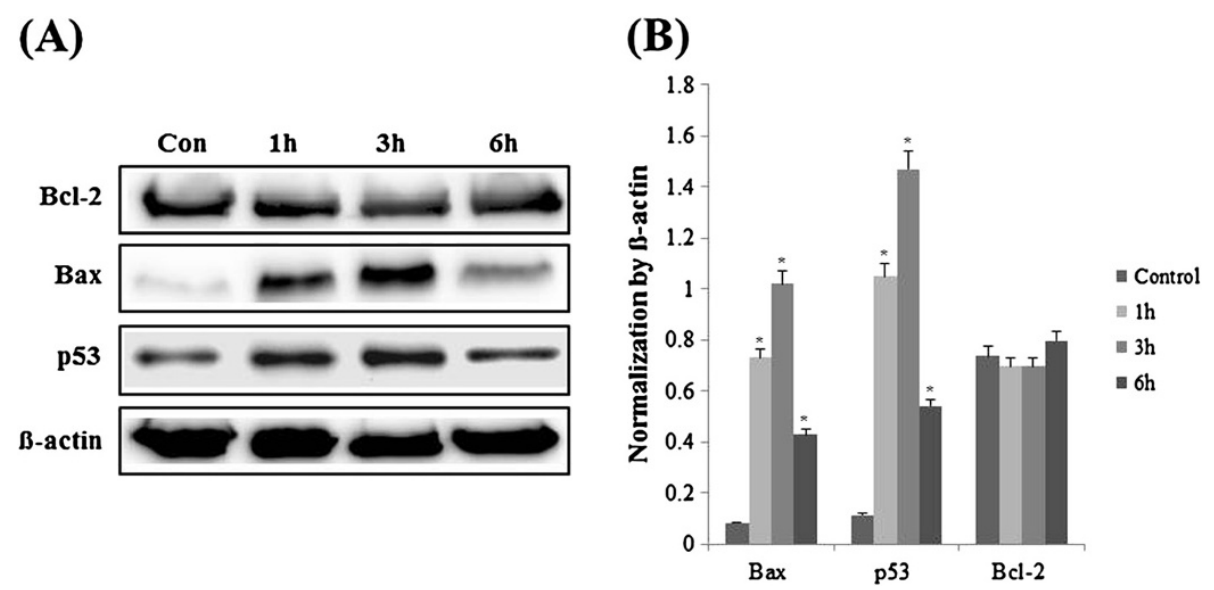

Figure 8 Effect of IS on the protein expression of Bcl-2, Bax, and p53 in MC3-T3 cells. (A) Representative immunoblots with anti-Bcl-2, anti-Bax, anti-p53, and anti- $\beta$-actin at 1 mM IS. (B) Densitometric analysis of Bcl-2, Bax, and p53, normalized by the data for $\beta$-actin. The data represent the mean \pm SEM ( $n=3$ for each group). 
hyperparathyroidism in CKD patients, PTH can be controlled by many drugs, including phosphate binders, vitamin D, and cinacalcet. However, no treatment specific to low-turnover bone disease is available. Elimination of uremic toxins could be an option for controlling low-turnover bone disease in CKD patients.

Our study suggested that IS-induced apoptosis might be mediated by free radical production. These findings are supported by many previous reports $[15,16]$. Several studies have shown that IS induces NADPH oxidase mRNA expression and increases its activity in various types of cells [17-19]. Namikoshi et al. reported that decreasing the serum concentration of IS by administrating the oral adsorbent AST120 reduces the expression of the NADPH oxidase component and alleviates oxidative stress in the aorta [20]. In our study, we did not determine NADPH mRNA expression or its activity, but it appears that increasing free radical production by adding IS may occur through an activation pathway of NADPH oxidase.

A list of uremic toxins has been provided by EUTox. The normal concentration of IS is $0.53 \mathrm{mg} / \mathrm{L}$ $(2 \mu \mathrm{M})$. The mean concentration of IS in uremic patients is $23.1 \mathrm{mg} / \mathrm{L}(\sim 100 \mu \mathrm{M})$, and the maximum concentration found in uremic patients was $44.5 \mathrm{mg} / \mathrm{L}$ [21].

\section{Conclusions}

Our data confirm that IS acts as a bone toxin by inhibiting osteoblast differentiation and inducing apoptosis via the caspase pathway. Further studies are required to elucidate whether elimination of IS could improve osteoblast differentiation in chronic renal failure.

\section{Abbreviations}

ALP: Alkaline phosphatase; DCF-DA: 2'-7'-dichlorofluorescein diacetate; CKD: Chronic kidney disease; CKD-MBD: CKD associated with mineral and bone disorders; IS: Indoxyl sulfate; MTT: 3-[4,5-dimethylthiazol-2-yl]-2,5-diphenyltetrazolium bromide; OAT: Organic anion transport; PNP: p-nitrophenol; PTH: Parathyroid hormone; RIPA: Radio-immunoprecipitation assay; ROS: Reactive oxygen species.

\section{Competing interests}

All the authors declare that they have no competing interests.

\section{Authors' contributions}

$\mathrm{KYH}$ carried out the molecular studies and PCR array. KKA carried out the molecular studies, FACS scan. GHW conceived of the study, and participated in its design and coordination. SHY participated in the design of the study and performed the statistical analysis. SHY participated in the design of the study and performed the statistical analysis. All authors read and approved the final manuscript.

\section{Acknowledgement}

This work was supported by the Soonchunhyang University Research Fund.

\section{Author details}

'Department of Microbiology, Soonchunhyang University Medical college, Cheonan, Korea. ${ }^{2}$ Department of Internal Medicine, Soonchunhyang University Cheonan Hospital, 31 Soonchunhyang 6gil, Dongnam-gu, Cheonan, Chungnam 330-721, Korea.
Received: 3 July 2013 Accepted: 27 November 2013

Published: 1 December 2013

\section{References}

1. Raff AC, Meyer TW, Hostetter TH: New insights into uremic toxicity. Curr Opin Nephrol Hypertens 2008, 17:560-565.

2. Barreto FC, Barreto DV, Liabeuf S, Meert N, Glorieux G, Temmar M, Choukroun G, Vanholder R, Massy ZA, European Uremic Toxin Work Group (EUTOx): Serum indoxyl sulfate is associated with vascular disease and mortality in chronic kidney disease patients. Clin J Am Soc Nephrol 2009, 4:1551-1558.

3. Jourde-Chiche N, Dou L, Cerini C, Dignat-George F, Brunet P: Vascular incompetence in dialysis patients-protein-bound uremic toxins and endothelial dysfunction. Semin Dial 2011, 24:327-337.

4. Yu M, Kim YJ, Kang DH: Indoxyl sulfate-induced endothelial dysfunction in patients with chronic kidney disease via an induction of oxidative stress. Clin J Am Soc Nephrol 2011, 6:30-39.

5. Shoji T, Wada A, Inoue K, Hayashi D, Tomida K, Furumatsu Y, Kaneko T, Okada N, Fukuhara Y, Imai E, Tsubakihara Y: Prospective randomized study evaluating the efficacy of the spherical adsorptive carbon AST-120 in chronic kidney disease patients with moderate decrease in renal function. Nephron Clin Pract 2007, 105:C99-c107.

6. Peng YS, Lin YT, Chen Y, Hung KY, Wang SM: Effects of indoxyl sulfate on adherens junctions of endothelial cells and the underlying signaling mechanism. J Cell Biochem 2012, 113:1034-1043.

7. Adijiang A, Goto S, Uramoto S, Nishijima F, Niwa T: Indoxyl sulphate promotes aortic calcification with expression of osteoblast-specific proteins in hypertensive rats. Nephrol Dial Transplant 2008, 23:1892-1901.

8. Iwasaki Y, Yamato H, Nii-Kono T, Fujieda A, Uchida M, Hosokawa A, Motojima M, Fukagawa M: Administration of oral charcoal adsorbent (AST-120) suppresses low-turnover bone progression in uraemic rats. Nephrol Dial Transplant 2006, 21:2768-2774.

9. Nii-Kono T, Iwasaki Y, Uchida M, Fujieda A, Hosokawa A, Motojima M, Yamato H, Kurokawa K, Fukagawa M: Indoxyl sulfate induces skeletal resistance to parathyroid hormone in cultured osteoblastic cells. Kidney Int 2007, 71:738-743.

10. Mozar A, Louvet L, Godin C, Mentaverri R, Brazier M, Kamel S, Massy ZA: Indoxyl sulphate inhibits osteoclast differentiation and function. Nephrol Dial Transplant 2012, 27:2176-2181.

11. Wang A, Ding $X$, Sheng $S$, Yao Z: Bone morphogenetic protein receptor in the osteogenic differentiation of rat bone marrow stromal cells. Yonsei Med J 2010, 51:740-745.

12. Jung KY, Takeda M, Shimoda M, Narikawa S, Tojo A, Kim DK, Chairoungdua A, Choi BK, Kusuhara H, Sugiyama Y, Sekine T, Endou H: Involvement of rat organic anion transporter 3 (rOAT3) in cephaloridine-induced nephrotoxicity: in comparison with rOAT1. Life Sci 2002, 70:1861-1874.

13. Miyashita T, Krajewski S, Krajewska M, Wang HG, Lin HK, Liebermann DA, Hoffman B, Reed JC: Tumor suppressor p53 is a regulator of bcl-2 and bax gene expression in vitro and in vivo. Oncogene 1994, 9:1799-1805.

14. Muteliefu G, Shimizu H, Enomoto A, Nishijima F, Takahashi M, Niwa T: Indoxyl sulfate promotes vascular smooth muscle cell senescence with upregulation of p53, p21, and prelamin A through oxidative stress. Am J Physiol Cell Physiol 2012, 303:C126-C134.

15. Goto S, Fujii H, Hamada Y, Yoshiya K, Fukagawa M: Association between indoxyl sulfate and skeletal resistance in hemodialysis patients. Ther Apher Dial 2010, 14:417-423.

16. Brancaccio D, Cozzolino M: CKD-MBD: an endless story. J Nephrol 2011, 24(Suppl 18):S42-S48.

17. Dou L, Jourde-Chiche N, Faure V, Cerini C, Berland Y, Dignat-George F, Brunet $P$ : The uremic solute indoxyl sulfate induces oxidative stress in endothelial cells. J Thromb Haemost 2007, 5:1302-1308.

18. Gelasco AK, Raymond JR: Indoxyl sulfate induces complex redox alterations in mesangial cells. Am J Physiol Renal Physiol 2006, 290:F1551-F1558.

19. Muteliefu G, Enomoto A, Jiang P, Takahashi M, Niwa T: Indoxyl sulphate induces oxidative stress and the expression of osteoblast-specific proteins in vascular smooth muscle cells. Nephrol Dial Transplant 2009, 24:2051-2058 
20. Namikoshi T, Tomita N, Satoh M, Sakuta T, Kuwabara A, Kobayashi S, Higuchi Y, Nishijima F, Kashihara N: Oral adsorbent AST-120 ameliorates endothelial dysfunction independent of renal function in rats with subtotal nephrectomy. Hypertens Res 2009, 32:194-200.

21. Duranton F, Cohen G, De Smet R, Rodriguez M, Jankowski J, Vanholder R, Argiles A, European Uremic Toxin Work Group: Normal and pathologic concentrations of uremic toxins. Am Soc Nephrol 2012, 23:1258-1270.

doi:10.1186/2050-6511-14-60

Cite this article as: Kim et al:: Indoxyl sulfate promotes apoptosis in cultured osteoblast cells. BMC Pharmacology and Toxicology 2013 14:60.

\section{Submit your next manuscript to BioMed Central and take full advantage of:}

- Convenient online submission

- Thorough peer review

- No space constraints or color figure charges

- Immediate publication on acceptance

- Inclusion in PubMed, CAS, Scopus and Google Scholar

- Research which is freely available for redistribution 